\title{
UNTAXED SOCIAL-MEDIA PROBLEM AND POTENTIAL SOLUTIONS
}

\author{
Dr. Fatih Kaplanhan \\ Istanbul Sabahattin Zaim University
}

\section{Cem Korkut}

Yildirim Beyazit University

\begin{abstract}
Advancement of internet innovation brings both pros and cons by changing the rules and dynamics of fields as trade, public service, education, entertainment, intelligence, and defense. The developments in web technology provided a lot of conveniences. On the other hand, this situation brought many problems because of lack of laws and rules in this field. One example of these challenges is those websites do not have branches in every country are not subject to taxation. This situation is directly related to the sovereign rights of the countries. Major international internet companies are only subject to tax in the countries where their headquarters are located and do not pay taxes in other nations where they earn money. Particularly in the developing countries, the tax loss reaches serious dimensions. This study will focus on the problem of social media taxation. Also, solution proposals will be presented especially for developing countries.
\end{abstract}

Keywords: Untaxed Income, Social Media, Taxation, Internet Taxation.

\section{INTRODUCTION}

The social media is the digital platform which allows following the simultaneous information sharing made possible by user-friendliness and fast communication, which have been introduced by new-generation web technologies in the broadest sense. The utilization of online networking increments in parallel with the internet use in the world. Online networking accounts, which both females and guys from all age bunches use for socialization, have turned into a financial reality. Advertisements, big data The term big data refers to the forms of data collected from different sources such as social media, blogs, photos, videos, and log files that have been turned into a meaningful and processable version. Marketing, social media advertisement and e-commerce etc. are among the components demonstrating the monetary impressions of the web all in all and web-based social networking specifically.

The internet service is offered and sold to users by access providers. Hardware infrastructure for the Internet-based 
works, on the other hand, is provided by hosting providers. Both access providers and hosting providers are mostly profit-seeking commercial enterprises. Content providers are the most profit-making actors of the internet market though they do not only have commercial purposes.

In a broad sense, enterprises offering internet service can be called internet service providers (ISPs). This definition covers any business, institution, or organization from internet cafes to International Telecommunication Union that offer internet service. Though ISPs have different structures in different countries, they provide internet access (mere conduit - EU directive definition) in general. However, besides the access service, ISPs also engage in server leasing, domain name hosting, hosting, application service providing, and content (information) providing (Ed. Uzel, Turkish Informatics Council, 2002:168). As the concept of "Internet Service Providing" covers all the services related to the web, the actors of the internet market are separately presented under the titles of access providers, hosting providers, and content providers here.

Real and legal persons that allow users to access the internet environment are referred to as internet access providers (IAPs) (Sari, 2011:47). IAPs function as a bridge between the web and those individuals who want to access it and make users access the internet for a specific fee and contract (Sinar, 2001:41). Mostly, ISPs are considered to cover IAPs though the activities performed by them are different in technical terms (Kiremitci, 2012:11).

A considerable part of the access providing service is offered by fixed telecommunications businesses as they keep communication and data flow channels under control. As communication has developed, even mobile phone companies provide internet access to many subscribers. Telecommunications businesses lease or transfer the lines that they have reserved from among the existing telephone lines to corporations or public institutions and organizations as internet connection ser-

Inquipy 2016/2 vice. In many countries, the right to establish and operate telecommunications infrastructure is either exercised by public institutions directly or granted to private sector enterprises under a contract signed with the public administration (Kiremitci, 2012:11-12).

Internet content refers to any information, document, picture, photo, video, database, and material that has been made accessible to users in the internet environment. Internet content provider (ICP), on the other hand, is the person or enterprise that produces and arranges content (Kiremitci, 2012:12). In general, people or establishments that provide content transfer a specific piece of information to the internet environment. For example, the owner of a webpage is a content provider. Those 
who prepare and present information (files) that are to be obtained via "downloading" are also content providers.

Web 2.0, which has started a new age in the field of technology, has led to a very fast development of social media platforms on the internet. One of the biggest influences of this development has been that www (i.e. world wide web) has stopped being a platform where only the data created, formed, and published by people exist and turned into an area that contains data continuously changed, formed, and developed through users' participation and cooperation. In this way, Web 2.0 has turned internet users from readers to content providers (Eraslan, 2015:9). It is not possible to make effective regulations about content providers within the internet law due to reasons such as the transformation of internet users to content providers thanks to web 2.0, the rapid increase in the number of internet users in the world, and the difficulty of identifying content providers.

Keeping all the relevant materials of websites such as photos and videos on servers is called hosting in general (Sari, 2011:33). In other words, hosting refers to storing and publishing the files belonging to websites via computers (web servers) that store and offer these data for users' access. Hosting provider, on the other hand, is the person or establishment that hosts the content contained in the internet environment in its servers and publishes it. This process and those who are engaged in this process are called hosting.

Every user can publish information or file on his computer connected to the internet in a way that is accessible to others. However, having a sufficient connection speed is required to publish a web page that can attract large masses. In this regard, well-equipped companies offer hosting service, which enables many users to connect webpages at a high speed, for fee simultaneously.

\section{ANALYSIS OF SOCIAL MEDIA USAGE}

As the Table 1 below shows, the rapid percentage change rapid in internet usage growth can be seen. Especially, the change in developing countries is quite evident. The world total is also high in internet usage rate, $45,00 \%$.

Almost half of world population is internet users and the change between 2000-2015 for a fifteen years' period is 806,0\%. Korea, United Kingdom and Japan are the top of the list and the internet usage rate is higher than $90 \%$ in these countries. The number of Facebook users reached 1,481,914,040 and the number of Twitter reached 232,000,000. These means the $20 \%$ of the world population uses Facebook. However, multiple accounts belonging to the same person are counted. Despite this double count for people, Facebook has significant power in the 
world.

In developing countries, the example of Turkey is very interesting. Although Turkey hosts only $1.07 \%$ of the world population, its Google usage rate is $3.11 \%$. The usage rates of Google as a search engine in different countries had been as following by 2014. Though not much, the internet is also used for educational purposes, engaging in research and examination, e-commerce, virtual shopping, internet banking, using e-state services and obtaining information about goods and services (Kilic, 2013:401-403).

Table 1: Internet Users, Top 20 Countries, June 2015|

\begin{tabular}{|c|c|c|c|c|c|c|}
\hline & Country & $\begin{array}{l}\text { Population } \\
\text { (2015 estimated) }\end{array}$ & $\begin{array}{c}\text { Internet Users } \\
(2000)\end{array}$ & $\begin{array}{l}\text { Internet Users } \\
\text { (2015) }\end{array}$ & $\begin{array}{l}\text { Usage } \\
\text { Rate }\end{array}$ & $\begin{array}{l}\text { Growth } \\
\text { rate }\end{array}$ \\
\hline 1 & Korea & $49,115,196$ & $19,040,000$ & $45,314,248$ & $92.3 \%$ & $138 \%$ \\
\hline 2 & United Kingdom & $64,767,115$ & $15,400,000$ & $59,333,154$ & $91.6 \%$ & $285 \%$ \\
\hline 3 & Japan & $126,919,659$ & $47,080,000$ & $114,963,827$ & $90.6 \%$ & $144 \%$ \\
\hline 4 & Germany & $81,174,000$ & $24,000,000$ & $71,727,551$ & $88.4 \%$ & $199 \%$ \\
\hline 5 & USA & $321,362,789$ & $95,354,000$ & $280,742,532$ & $87.4 \%$ & $194 \%$ \\
\hline 6 & France & $66,132,169$ & $8,500,000$ & $55,429,382$ & $83.8 \%$ & $552 \%$ \\
\hline 7 & Russia & $146,267,288$ & $3,100,000$ & $103,147,691$ & $70.5 \%$ & $3,227 \%$ \\
\hline 8 & Italy & $60,795,612$ & $13,200,000$ & $37,668,961$ & $62.0 \%$ & $185 \%$ \\
\hline 9 & Turkey & $77,695,904$ & $2,000,000$ & $46,282,850$ & $59.6 \%$ & $2,214 \%$ \\
\hline 10 & Brazil & $204,259,812$ & $5,000,000$ & $117,653,652$ & $57.6 \%$ & $2,253 \%$ \\
\hline 11 & Iran & $81,824,270$ & 250 & $46,800,000$ & $57.2 \%$ & $18,620 \%$ \\
\hline 12 & Egypt & $88,487,396$ & 450 & $48,300,000$ & $54.6 \%$ & $10,633 \%$ \\
\hline 13 & Nigeria & $181,562,056$ & 200 & $92,699,924$ & $51.1 \%$ & $46,250 \%$ \\
\hline 14 & China & $1,361,512,535$ & $22,500,000$ & $674,000,000$ & $49.5 \%$ & $2,896 \%$ \\
\hline 15 & Mexico & $121,736,809$ & $2,712,400$ & $59,200,000$ & $48.6 \%$ & $2,083 \%$ \\
\hline 16 & Vietnam & $94,348,835$ & 200 & $45,579,922$ & $48.3 \%$ & $22,690 \%$ \\
\hline 17 & The Philippines & $109,615,913$ & $2,000,000$ & $47,134,843$ & $43.0 \%$ & $2,256.7 \%$ \\
\hline 18 & Indonesia & $255,993,674$ & $2,000,000$ & $73,000,000$ & $28.5 \%$ & $3,550.0 \%$ \\
\hline 19 & India & $1,251,695,584$ & $5,000,000$ & $354,000,000$ & $28.3 \%$ & $6,980.0 \%$ \\
\hline 20 & Bangladesh & $168,957,745$ & 100 & $44,625,000$ & $26.4 \%$ & $44,525.0 \%$ \\
\hline
\end{tabular}


Table 2: Search Engines and Market Shares (Moran \& Hunt, 2015)

\begin{tabular}{|c|c|c|}
\hline Search Engine & $\begin{array}{l}\text { Market } \\
\text { Share }\end{array}$ & The Market Shares of Search Engines \\
\hline Google & $53.74 \%$ & $\begin{array}{ccc}\text { Yahoo! } & \text { AOL } & \text { Ask Other } \\
4 \% & 0 \% & 0 \%\end{array}$ \\
\hline Baidu & $31.32 \%$ & \\
\hline Bing & $10.81 \%$ & $11 \%$ \\
\hline Yahoo! & $3.52 \%$ & \\
\hline $\mathrm{AOL}$ & $0.15 \%$ & $\begin{array}{c}\text { Google } \\
54 \%\end{array}$ \\
\hline Ask & $0.07 \%$ & \\
\hline Other & $0.39 \%$ & \\
\hline Total & $100.00 \%$ & \\
\hline
\end{tabular}

Table 3: Usage of Google as search engine

\begin{tabular}{|l|c|}
\hline Country & Usage of Google as search engine \\
\hline Turkey & $96.0 \%$ \\
\hline France & $91.0 \%$ \\
\hline USA & $67.3 \%$ \\
\hline United Kingdom & $67.3 \%$ \\
\hline Russia & $34.7 \%$ \\
\hline Korea & $2.5 \%$ \\
\hline China & $1.6 \%$ \\
\hline
\end{tabular}

Table 4: Social Media Usage in World

\begin{tabular}{|r|l|}
\hline The number of Facebook members on 30.09.2015 (World) & $1,481,914,040$ \\
\hline The number of Twitter users in 2014 (World) & $232,000,000$ \\
\hline
\end{tabular}

\section{APPROACHES TO THE TAXATION OF INTERNET PLAT- FORM/SOCIAL MEDIA}

By the principle of sovereignty, governments across the world tax the individuals and enterprises that make a profit in their country according to taxing principles. Hence, they embark on new quests, make new regulations, or reach various settlements to tax e-commerce and social 
media, which are becoming more and more widespread every passing day. Attempts to tax foreign enterprises which are headquartered abroad but gain revenue within the boundaries of the country, their taxation, obstacles to their taxation, and solution recommendations in this matter, which have been on the agenda both in Turkey and across the world, are handled under separate titles.

\subsection{Approaches and Attempts to Tax Social Media in the World}

OECD's general approach to the taxation of e-commerce is the application of tax rules applied to conventional commerce to e-commerce. No discriminatory taxation must be employed due to e-commerce, and there must be a fair sharing of tax assessments among countries. However, traditional rules do not allow governments to exercise their sovereignty authorities in e-commerce activities (Oz, 2015). The G20 states have charged OECD with preparing a plan for preventing the companies that raise their profit by causing loss of tax from engaging in such actions (Khadem, 2015); however, no result has been achieved in this matter yet.

As tax is the money the state gratuitously collects to meet public expenditures based on its sovereign power, causing the state to suffer the loss of tax means a violation of sovereignty. Countries take various measures to prevent loss of tax based on their own economic perspectives. For example, the state policy of People's Republic of China concerning internet governance can be summarized under the following three main titles about internet usage: (1) No country is allowed to intervene in any other country in a way that harms its benefits, (2) Every country has to have equal rights, (3) Countries have to respect right to national and international internet governance (Lin, 2015). At this point, it is possible to state that China-based its state policy of internet usage on sovereignty. It is known that China, which goes for country's sovereignty rather than freedoms, restricts the commercial dimensions of internet platforms that are headquartered abroad within the boundaries of the country. In this way, it has allowed the internet platforms headquartered in China to develop and become global brands. It is important that China brings the phenomenon of sovereignty, which is a new issue for the internet platform, up for discussion.

This is the case in the East, and economic sanctions and practices concerning companies with foreign capital are no different in the West. For instance, with the regulations contained in FATCA (Foreign Account Tax Compliance Act) put into force by the U.S. Department of Treasury in 2010, non-US financial institutions (foreign financial institutions) are obliged to report the assets of those who are liable to tax 
in the USA among their customers. The main purpose of these regulations, which prescribe sanctions on non-US financial institutions, is to hold and record all revenues of those who are liable to tax in the USA. Foreign financial institutions have to report the assets of those who are liable to tax in the USA among their customers based on the threshold values determined by the U.S. Internal Revenue Service (IRS). According to this, real persons whose total asset is over $\$ 50,000$ and legal persons whose total asset is over $\$ 250,000$ have to be reported.

The situation of foreign financial institutions that do not engage in any effort to identify their customers who are liable to tax in the USA and do not report such customers may vary depending on whether or not an intergovernmental agreement has been made. An agreement can be made with the USA based on two separate models. The first one is that an agreement is signed between the US government and other governments. The second one is an agreement that signed between the USA and the financial institution operating outside the borders of the USA. Withholding shall be applied at a rate of $30 \%$ of the US revenues of foreign financial institutions by the agencies authorized by IRS. Based on the procedures and principles of FATCA, it can be said in brief that the USA aims to tax the foreign revenues of its citizens and those who are liable to tax in the USA (whether they are social media companies or not) by placing sanctions on financial institutions and even governments that are not US citizens or liable to tax in the USA or located within the boundaries of the USA.

In the United Kingdom, which is another western country where some steps are taken to tax social media, certain decisions have been taken to keep the social media enterprises that operate within the boundaries of the country liable to corporation tax, just like other companies. In addition, it has been decided in the United Kingdom that any registered company including Twitter is obliged to pay the corporation tax determined over the total profit. Additionally, some steps are being taken through various regulations and agreements to assure that websites such as Google, Twitter, and Facebook pay some amounts of taxes to the United Kingdom although they must not be subjected to double taxation and have to pay their taxes to the USA as they are headquartered in the USA even if they make their main profits within the boundaries of the United Kingdom. As an interesting detail on this issue, upon Matt Brittin, who is one of the senior officials of Google in the United Kingdom, stating in the Public Accounts Commission of the parliament that they have chosen Ireland due to the favorable corporation tax of $12.5 \%$ and thus emphasizing that they do nothing illegal, Margaret Hodge, the chair of the commission, said to the company of- 
ficials that they blame them for acting unethically, not illegally, thereby stressing the need for an ideal legal sanction rather than an existing legal sanction in this matter. Just like China, the first concern of the United Kingdom on this issue is sovereignty and ethics rather than the economy. Its economic aspect is handled only after these two elements are ensured (BBC, 2016).

In Australia, which is another representative of the West (i.e. liberal system), some steps are taken to tighten taxing rules by using the federal budget, to impose penalties doubling the amount of unpaid taxes, and to demand the relevant amounts with their interests in an attempt to prevent the unbalanced distribution in the profits made and the taxes paid by multinational companies that are liable to a low tax rate or no tax at all. In this way, Australia seems to intend to keep the amounts of penalties big and thus collect the taxes that have not been paid so far. Though it has not indicated the companies that shall be exposed to such sanctions, the prevailing belief in Australia is that 30 multinational companies have been paying much fewer amounts of tax than they have to pay through false or artificial tax regulations. For example, in 2013, Apple paid only 56 million dollars for a revenue of 6 billion dollars and Google paid 4.1 million dollars for a revenue of 268 million dollars in Australia. In other words, Australia, which is taking steps to tax the internet, focuses on the big gap between the profits multinational companies make and the amounts of tax they pay (Heber, 2015).

As to the situation in Italy; Google, Italian Ministry of Economy and Finance, and the Office of the Attorney General in Milan reached an agreement at the end of long negotiations between Google's officials and the Italian government. Under this agreement, a tax of 320 million euros was imputed to Google for the advertising revenues it gained in Italy between 2008 and 2013 (Fonte \& Jones, 2015). Although Google is not a person liable to tax in Italy according to the Italian legislation, negotiations were held and an agreement was reached for it to pay tax over the advertising revenue it earned in Italy. It is remarkable that an $2016 / 2$ agreement was reached despite the inadequacy of the legislation.

\section{TRICKS IN THE TAXATION OF SOCIAL MEDIA AND UN- TAXED SOCIAL MEDIA PROBLEM}

In recent years, there has been a remarkable increase in the number of companies that receive advertising service from the firms, especially the social media enterprises headquartered abroad (Iyigun, 2010). Rise in the amount of money paid to social media enterprises in return for the advertising service received brings forward questions such as "Do these social media enterprises cause loss of tax?" and "To what extent 
do these social media enterprises cause loss of tax?". It is necessary to explore whether the tax is collected from social media enterprises headquartered abroad (indirectly through withholding or directly) regarding corporation tax and VAT separately.

International agreements determine the legal framework of foreign relations. Double tax agreements (DTAs) determine the framework of countries' taxation authorities and rules. The binding force of the rule of international law generates an obligation to comply with these rules. International agreements are considered to be above the law. Thus, conflict of authority emerges when international agreements and national tax laws contain different provisions on the same issue. In such a case of inconsistency, international agreements are taken as the basis (Yalt1, 2006).

International double taxation emerges when the taxation authorities of two states conflict on the same taxpayer or on the same tax issue while they are exercising their taxation authorities based on their sovereignty. Tax agreements are the most effective way of preventing and eliminating such conflicts. These agreements, which are one of the sources of the international tax law, try to separate the conflicting taxation authorities of the states at the points where such conflicts take place. What they take as the basis is assigning certain components of revenue to the taxation authority of one or both of the relevant states (Soner, 2015).

International taxation involves two basic principles about states' exercising their economic sovereignty $(\mathrm{Oz}, 2015)$ : the principle of territoriality and principle of personality. According to the principle of territoriality, laws have to be applied to everybody in the country, domestic or foreign. The principle of personality, on the other hand, prescribes that a country's citizen is subject to the laws of the country wherever he is. It is clear that as the social media enterprises headquartered within the boundaries of any country are mostly stock corporations in practice and make their profits inside the country, their profits will be subject to corporation tax. However, there is need to focus on how to tax the profits of the social media enterprises that are headquartered abroad but make business profits inside the country. Taxation of social media must $2016 / 2$ be handled on the basis of limited liability and corporation's business profit.

Despite the above-mentioned general framework of the international rules concerning the taxation of persons with limited liability based on traditional trading methods, these conditions change when the virtual world is in question. Especially due to the problems about the definition of permanent establishment, virtual merchants can operate in 
a country without having a fixed permanent establishment or permanent representative. They can pass through customs frontiers, where states' taxation authorities begin, thousands of times within the same day. Thus, states face with the problem of taxation $(\mathrm{Oz}, 2015)$. Google, Facebook, and Twitter, which are among the foreign enterprises headquartered abroad, do not disclose their turnovers and advertising revenues on the basis of country by with the principle of confidentiality of tax payers.

Considering that some functions of Google, Facebook, and Twitter concerning the sales of services are not used in some countries such as China and Russia. Thus, the sanctions of these countries can give us insight.

\section{SOME SOLUTIONS TO UNTAXED SOCIAL MEDIA}

The double tax agreements, the current situation of legal regulations, and their interpretations and implementation fail to grasp the trading methods carried out over the new virtual internet environment. They even make it difficult for countries to collect the tax it deserves by exercising its sovereign right. It does not seem possible for a ministry or public institution to struggle with these new methods by itself. As what is in question here is tax, one must look at the tax legislation and tax-related international agreements first.

As a general rule, taxation of the profits made by enterprises with limited liability can be handled under two separate titles: business profits and other profits. In the case of other profits (i.e. Incomes from Agriculture, Fees, Self-Employment Earnings, Incomes from Immovable Property, Incomes from Movable Property, Other Incomes and Earnings), persons with limited liability indirectly pay corporation tax through deductions. However, corporation tax is not paid through deductions in the case of business profits. As the profits made by the social media enterprises headquartered abroad are business profits, they have to have either full liability or limited liability to pay tax. The social media enterprises headquartered abroad do tax planning and open permanent establishments in countries with low tax rates in order to avoid taxation by acting prudently. In addition, they exert maximum effort not to pay taxes to other countries as well. In this regard, they avoid being a tax payer in countries.

Amending law taxes is not enough to tax these foreign enterprises headquartered abroad. Even international agreements hinder taxation. Accordingly, it is necessary to re-handle, review, and adjust international double tax agreements, laws, and communique altogether so that the countries can tax the revenues gained within its boundaries by its sovereignty. 
The provisions of international agreements are taken as basis in the event that duly enacted international agreements concerning basic rights and freedoms and domestic laws involve different provisions on the same issue. Therefore, it is necessary to adjust the provisions preventing collecting taxes in international agreements before tax or internet legislation. Double tax agreements between countries to be made with other countries must re-define the concepts of "permanent establishment" and "business profit" in accordance with the newly-developing technology and internet law. In other words, these concepts must be re-defined in a way that does not prevent taxation of foreign enterprises headquartered abroad.

For a person or enterprise to be taxed within the scope of limited liability, such person or enterprise has to gain revenue through the activities they perform in certain country or are deemed to be performed in that country. Based on the principle of territoriality, this bond between countries and the gained revenue constitutes legitimacy to tax the revenues gained within its boundaries as a state of source. States can tax the revenues gained within their boundaries of sovereignty only where such bond can be established (Oner, 2015). In this regard, rules and concepts of law must be updated both in international agreements and in laws and communiqués in accordance with the changing technological conditions. Accordingly, for enterprises with limited liability whose registered office and principal office are not situated in a certain country to be taxed because they make business profits in that country, they have to have a permanent establishment or permanent representative and earn their profits through such permanent establishment or permanent representative in that country.

Although the enterprises headquartered abroad such as Google, Twitter, and Facebook are relevant to the definition of limited liability. Thus, they cannot be taxed as they have no permanent establishment or permanent representative in country. In today's technological conditions, one does not need to have a permanent establishment or permanent representative in a country to earn a business profit there. Not opening a permanent establishment or not having a permanent representative in other countries is more preferable for these kinds of foreign enterprises that make profit over the internet platform with their headquarters abroad as it reduces costs.

Amending international double tax agreements and tax legislation may not be enough to tax foreign enterprises headquartered abroad that gain profit over the internet platform. In such a case, sanctions must be put into action in the country. That is to say, the internet legislation must be amended besides the tax legislation. This will separately be dis- 
cussed under the title of Taxation of Social Media through Amendment of the Internet Legislation. Interpretation in tax law refers to the explanations made by considering various criteria in order to apply abstract law rules to concrete legal situations, processes, and events. Interpretation does not bring a new provision, rather shows the way provisions of the existing laws are to be implemented by making them understandable. According to teleological interpretation, which is among methods of interpretation in the lax law, the purpose of a law is important. It must be interpreted based on the requirements of the age.

Although there is a need to make amendments in the existing legislation and international agreements, communiqués can make it possible to reinterpret the definitions contained in the existing legislation and their components to deem the computer screen with internet connection as a permanent establishment or permanent representative in the countries.

Besides the fact that computer screens work like branches of Google, Facebook, and Twitter headquartered abroad, the realities about the following four constituents of a commercial branch are also remarkable;

- Computer screens are directly affiliated with the central office via software,

- Google, Facebook, and Twitter can independently and directly perform transactions with the third parties (residing in a certain country) via computer screens.

- Though their central offices are located in the USA and Dublin, social media enterprises can make sales in any place different from their central offices if such place has internet connection. Thus, separation of power is true for them. Moreover, as every consumer performs their operations over the screen like a branch employee/operator, separation of management is also there,

- There is a similarity in terms of the activities carried out on the computer screen, which is used as a branch, within the scope of the limited authority granted by the central offices of social media enterprises. The primary area of activity of the central office is selling advertising services. Sales activities can be performed through branches in the form of screens.

It is clear above that computer screens with internet connection incorporate all these four components.

As the following acts performed through a branch, which have been discussed above in detail, can be performed via computer screens with internet connection, these screens can be deemed branches:

- Carrying out the same activities with the central office,

- Establishing direct connections with customers, 
- Performing some of the activities performed by the central office,

- Making agreements based on offer and acceptance.

As a branch is considered to be a component of an enterprise both in international agreements and in tax legislation, if computer screen is deemed/interpreted as a branch, the business profits made by foreign enterprises headquartered abroad in a certain country can be taxed. Given the fact that companies such as Google, Facebook, and Twitter can make sales (provide services such as advertising services) over all the computer screens with internet connection under the operatorship of customers/consumers just like a branch selling commercial goods in a fixed place, it is clear that each computer screen with internet connection is a branch of social media enterprises.

The publications in the internet environment are offered to the use of subscribers by the access providers. The broadband (fiber) infrastructures established through investments are mainly used by social media enterprises that play the leading role in the world. The traffic created particularly by video and message sharing platforms uses a considerable part of the infrastructure. If the issue is analyzed through the metaphor of highways, the highways represent the internet infrastructure; the vehicles traveling on the highways represent social media actors; and the drivers represent the users. Just like the drivers who do not pay taxes are obliged to use free highways, social media enterprises not paying taxes have to use narrow-band infrastructure. Hence, the conditions of competition between the taxpaying and non-taxpaying enterprises can be based upon the principle of justice. Within the context of highways, this method is not deemed as a violation of the $13^{\text {th }}$ article of The Universal Declaration of Human Rights by any of the countries. Accordingly, the right to communication defined in the $12^{\text {th }}$ article is not considered to be violated, either.

Having not adequate domestic platforms leads to dependency on the social media enterprises headquartered abroad. This dependency is one of the reasons underlying the lack of relevant legal regulations. It is necessary to support, coordinate, monitor, encourage, and conduct scientific and technological research \& development activities via the hands of government. There is also a need to develop programs and projects for this purpose. The scientific and technological policies must be determined reasonably and steadily especially in developing countries. Centers and institutes must be established to raise competitive capacity based on inventions and innovations, to conduct studies for the enhancement of economic and social development and the security of the country, and to reinforce technological infrastructure. The techno- 
logies that are developed in the centers, institutes, and units conducting research and development activities must be used for production in relevant areas and be promoted. Appropriate environments and management methods must be prepared to utilize them more easily. Also, such technologies must be transformed into commercial assets that contribute to the economy of the country as well as its industrial and social development. Incentive and support systems aimed at promoting active participation of public and private sectors in technological research, development, and innovation activities must be developed and put into action. Legal persons and funds operating with the aim of commercializing the inventions that have potential to develop must be encouraged, and scientific and technological culture must be improved throughout the country.

Another important issue for the development of domestic internet platform and social media products is to prevent unfair competition between domestic social media products and foreign ones. As competition is a process acting as an instrument that ensures the functionality of the market economy, it is not possible for market economy to operate healthily in the absence of the conditions that create competition. Naturally, economic units in the competitive environment have a continuous tendency to avoid competition. Market economy has an unstable internal structure and dynamic. Therefore, it is necessary to have a healthy competition process in order for market economy to operate effectively. Basically, competition against good faith or its disruption through deceptive behaviors is called "unfair competition". The governments have to undertake important tasks for the establishment and maintenance of competition in their countries. It is inevitable for the government to employ a conscious competition policy. Preservation and development of a market organization based on competition is the responsibility of the competition policy. There is a need for a dynamic process of competition between the rival enterprises in order for market economy to operate healthily. Not the powerful one, but the successful one must make itself accepted in this process. If the government does not have a competition policy, not the successful one but the powerful one dominates the market, eliminating the competition. Therefore, establishment and maintenance of competition and ensuring its continuity are the main responsibilities of the government in the economies where market organization is effective. In market economies, competition policy is vital for the general economy policy. Indeed, disruption in the competition process, which constitutes the central element of the market system, threatens the entire economic system. Therefore, competition must be created by the hands of the government. Creation of healthy markets, 
encouraging entrepreneurs, effective distribution of limited sources of the country, and effective use of such sources are only possible through a powerful bureaucracy with competence and capacity. Unearned income emerges in the absence of competition. In communities where unearned income prevails, the general tendency is not to create a competitive environment and reduce unearned income, but to fight for taking a share from the unearned income created (Kumcu, 2008:11).

In this sense, the enterprises dominating the market via agreements, decisions, and practices that hinder, disrupt, or limit the competition in the markets as well as their abuse of such dominance have to be prevented from acting in this way. In this sense, appropriate regulations and supervisions must be performed to protect the competition. Furthermore, all kinds of legal proceedings and behaviors involving merger and acquisition through the abuse of dominant positions in the market or reinforcing the current dominating conditions that results in a considerable decrease in competition must be dealt with.

\section{CONCLUSION}

Relevant organizations need to have well-established fundamental initiatives concerning the duties written in their laws. Individuals, companies, organizations, and states that cannot comprehend and adapt to the changes in the field of internet, where rapid developments are experienced in a variety of areas including public services, commerce, game sector, intelligence, and cyber army, are destined to be behind the times. In an internet platform where country sovereignty and human factor are not at the center, inequality and injustice will increase in proportion to the speed of technological development. The internet is the common home of humanity. The fact that websites are open to access all around the world causes a big gap between their responsibilities and profits. In this section, recommendations are put forward about the practices that can minimize such difference.

The revision of international agreements: Double tax agreements made with other countries should be terminated if necessary by considering the time during which termination is not allowed, which is specified in the termination or abolishment articles of agreements for countries. If the time during which termination is not allowed is still continuing. The countries' interest and the cost of termination should be analyzed. As a result, the agreements whose termination will bring more benefit than its cost should be terminated. In the double tax agreements to be made with other countries from now on, attention should be focused on the time during which termination is not allowed and defin- 
itions of permanent establishment and business profit. Such definitions should be updated by the newly-developing technology and internet law in a way that does not prevent the taxation of foreign enterprises headquartered abroad.

The revision of tax legislation in domestic law: For people with limited liability whose neither registered office nor principal office is situated in a certain country to be taxed for the business profits made in this country; they have to have a permanent establishment or permanent representative in this county and earn their profits through such permanent establishment or permanent representative. Although Google, Twitter, and Facebook, which are among the foreign enterprises headquartered abroad, are considered to be persons with limited liability pursuant. Thus, they cannot be taxed as they have no permanent establishment or permanent representative in this country. In today's technological conditions, one does not need to have a permanent establishment or permanent representative in a country to earn a business profit there. Not opening a permanent establishment or not having a permanent representative in other countries is more preferable for these kinds of foreign enterprises that make profit over the internet platform with their headquarters abroad as it reduces costs. Hence, the conditions required for enterprises with limited liability to make business profit in this country indicated. So, the laws in countries should be amended in accordance with today's technological conditions and international agreements. Concepts such as full liability, limited liability, permanent establishment, principal office, branch, and permanent representative should be defined in the laws and union of concepts should be ensured by making references to these definitions from other laws such as Corporation Tax Laws, the Income Tax Laws, and VAT Laws in countries. The authorities should be provided with a highly limited discretionary power to determine the sectors and enterprises who are liable to tax, those who have joint liability, deduction rates to be applied, and tax rates. Such authority should be determined via laws.

Re-interpretation of some definitions in the tax legislation: According to teleological interpretation, which is among methods of interpretation in the lax law, the purpose of a law is important. It should be interpreted based on the requirements of the age. In this regard, necessary communiques should be prepared by relevant ministries based on the interpretation that computer screens with internet connection can be deemed as branches of enterprises because the following acts, which are true for an ordinary branch of an enterprise, can be performed via computer screens; carrying out the same activities with the central office, establishing direct connections with customers, performing some 
of the activities performed by the central office, and making agreements based on offer and acceptance.

The revision of internet legislation: As the fact that the taxpaying service providers headquartered inside in a certain country and non-taxpaying service providers headquartered abroad provide service through the same infrastructure leads to unfair competition, necessary legislative and infrastructural steps should be taken for them to serve at different bandwidths.

Developing countries must be aware of the current tax loss for social media. The loss is big enough to heed. The rate of loss is important for many developing countries. Moreover, the giving up to taxing social media in developing countries may lead to further concessions. This issue should be taken to the agenda of developing countries and the necessary measures should also be taken immediately.

\section{REFERENCES}

BBC, (30.03.2015). Starbucks, Google ve Amazon mecliste ifade verdi, http://www. bbc.com/turkce/ekonomi/2012/11/121113_tax_avoidance

Ed. Uzel, G. (Turkiye Bilişim Şurası). Hukuk Calışma Grubu Raporu: İnternet Servis Saglayıcılarinin Sorumluluklarl ve Internet Yayıncıllgi. Ankara: Turkiye Bilişim Dernegi.

Eraslan, L. (2015). Sosyal Medya Toplum Araştırma. Beta Yayınları: İstanbul.

Fonte, G., \& Jones, G. (2015, 09 30). Italy's Renzi faces uphill struggle over Google Tax plan. http://www.reuters.com/article/us-italy-tax-internet-analysis-idUSKCNORU1HS20150930

Heber, A. (2015, 05 11). Australia will get a 'Google tax' in the federal budget. http:// www.businessinsider.com.au/australia-will-get-a-google-tax-in-the-federalbudget-2015-5

InternetWorldStats. (2015, 11 18). Internet Usage in Europe. http://www.internetworldstats.com/stats4.htm\#europe

InternetWorldStats. $(2015,11$ 18). Top 20 Countries with the Highest Number of Intenet Users. http://www.internetworldstats.com/top20.htm

Iyigun, R. (2010, 12 06). Google, Twitter ve Benzeri Firmalardan Turkiye'de Alinan Reklam Hizmetlerinin Vergisel Boyutu ve Muhasebe Uygulaması. http://www. muhasebetr.com/ yazarlarimiz/recepiyigun/002/

Khadem, N. (2015, 05 01). Google paid \$11.7m tax in 2014, but says 'there's more we can do. www.smh.com.au: http://www.smh.com.au/business/google-paid117m-tax-in-2014-but-says-theres-more-we-can-do-20150430-1mxbx7.html

Kilic, A. (2013). Devlet Eli Ille İnternet İcerik Duzenlemesi Sorunu: TiB Ornegi. Konya: Yayınlanmamış Doktora Tezi Selcuk Universitesi.

Inquipy

2016/2 
Dr. Fatih Kaplanhan, Cem Korkut

Kiremitci, U. (2012). Internetin Gelişimi ile Birlikte Ortaya Cıkan Sorunlar ve Internetin Duzenlenmesine Yonelik 5651 Sayll Yasanın Getirdigi Onlemler, Uygulama Sorunlar ve Cozum Onerileri. Ankara: Bilgi Teknolojileri ve İletişim Kurumu.

Kumcu, E. (2008). Rekabet Uzerine Denemeler. Ankara: Rekabet Kurumu Yayınları. Lin, T. (2015). Internet Governance Forum.

Moran, M., \& Hunt, B. (2015, 12 23). Search Engine Marketing. http://semincbook. com/country-search-engines/

Oner, C. (2015, 12 23). Dar Mukellefiyette Ticari Kazancin Turkiye'de Elde Edilmiş Sayılmadıg Haller Uzerine. http://www.kazanci.com/kho2/hebb/ files/dsp.php? $\mathrm{fn}=$ makale-cihatoner-1.htm \&kw $={ }^{\prime} \mathrm{dar}+\mathrm{m} \% \mathrm{C} 3 \%$ BCkellef \# Toc403479485

Oz, S. (2015, 11 30). Twitter'in Vergilendirilmesi. Vergi Sorunları Dergisi: http:// www.vergisorunlari.com.tr/yazi.aspx?yazino $=88$

Sari, E. (2011). 5651 Sayılı Kanun Kapsamında Erişim Saglayıcılıgı Kavramı: Getirilen Hak, Yukumluluk Ve Sorumluluklar, Dunya'daki Uygulama Ornekleri. Ankara: Bilgi Teknolojileri ve İletişim Kurumu.

Sinar, H. (2001). Internet ve Ceza Hukuku. Beta Yayınları: İstanbul.

Soner, C. (2015, 12 23). Cifte Vergilendirmeyi Onleme Anlaşmalart. http://www. kazanci.com/ kho2/hebb/files/dsp.php?fn=makale-cerensoner-2.htm\&kw$={ }^{\prime}$ dar $+\mathrm{m} \% \mathrm{C} 3 \%$ BCkellef $\#$ fm

Yalti, B. (2006). İnsan Hakları Avrupa Sozleşmesinin Vergi Hukukunda Kaynak Degeri Uzerine. Hukuk Araştırmaları Dergisi, Doc.Dr. Mehmet Somer'e Armagan. 